NASA/TM-1998-208832

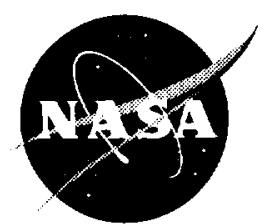

\title{
Effects of Fiber Coating Composition on Mechanical Behavior of Silicon Carbide Fiber-Reinforced Celsian Composites
}

Narottam P. Bansal and Jeffrey I. Elderidge

Lewis Research Center, Cleveland, Ohio

National Aeronautics and

Space Administration

Lewis Research Center 


\section{Acknowledgments}

Thanks are due to John Setlock for composite processing, Ron Plillips for flexural strength measurements, Ralph Garlick for X-ray diffractions analysis, Darwin Boyd for scanning Auger analysis, and Larissa Rodzianko for assisting with the fiber push-in data analysis.

Trade names or manufacturers' names a ee used in this report for identification only. This usage does nc $t$ constitute an official endorsement, either expressed or implied, by the National Aeronautics and Space Administration.

Available from

NASA Center for Aerospace Information 7121 Standard Drive

Hanover, MD 21076

Price Code: A03
National Technical Information Service 5285 Port Royal Road Springfield, VA 22100

Price Code: A03 


\title{
EFFECTS OF FIBER COATING COMPOSITION ON MECHANICAL BEHAVIOR OF SILICON CARBIDE FIBER-REINFORCED CELSIAN COMPOSITES
}

\author{
Narottam P. Bansal and Jeffrey I. Eldridge \\ National Aeronautics and Space Administration \\ Lewis Research Center \\ Cleveland, $\mathrm{OH} 44135$
}

\begin{abstract}
SUMMARY
Celsian matrix composites reinforced with Hi-Nicalon fibers, precoated with a dual layer of $\mathrm{BN} / \mathrm{SiC}$ by chemical vapor deposition in two separate batches, were fabricated. Mechanical properties of the composites were measured in three-point flexure. Despite supposedly identical processing, the composite panels fabricated with fibers coated in two batches exhibited substantially different mechanical behavior. The first matrix cracking stresses $\left(\sigma_{\mathrm{nk}}\right)$ of the composites reinforced with fibers coated in batch 1 and batch 2 were 436 and $122 \mathrm{MPa}$, respectively. This large difference in $\sigma_{\mathrm{mc}}$ was attributed to differences in fiber sliding stresses $\left(\tau_{\text {friction }}\right), 121.2 \pm 48.7$ and $10.4 \pm 3.1 \mathrm{MPa}$, respectively, for the two composites as determined by the fiber push-in method. Such a large difference in values of $\tau_{\text {friction }}$ for the two composites was found to be due to the difference in the compositions of the interface coatings. Scanning Auger microprobe analysis revealed the presence of carbon layers between the fiber and $\mathrm{BN}$, and also between the $\mathrm{BN}$ and $\mathrm{SiC}$ coatings in the composite showing lower $\tau_{\text {friction }}$. This resulted in lower $\sigma_{\text {mc. }}$ in agreement with the ACK theory. The ultimate strengths of the two composites, 904 and $759 \mathrm{MPa}$, depended mainly on the fiber volume fraction and were not significantly effected by $\tau_{\text {friction }}$ values, as expected. The poor reproducibility of the fiber coating composition between the two batches was judged to be the primary source of the large differences in performance of the two composites.
\end{abstract}

\section{INTRODUCTION}

Silicon carbide fiber reinforced celsian matrix composites are being investigated (refs. 1 to 6 ) as high-temperature structural materials for applications in the hot sections of turbine engines. Recently, we observed a large difference in the values of the first matrix cracking stresses of $\mathrm{BN} / \mathrm{SiC}$ coated $\mathrm{Hi}-\mathrm{Nicalon}$ fiber-reinforced $0.75 \mathrm{BaO}-0.25 \mathrm{SrO}-\mathrm{Al}_{2} \mathrm{O}_{3}-2 \mathrm{SiO}_{2}$ (BSAS) celsian composites made under identical processing conditions, but using fibers which were coated at two different times by the same vendor. The primary objective of the current study was to investigate the reasons for this large difference in the behavior of the two composites. The mechanical properties were measured in three-point flexure. The fiber/matrix interface was characterized by the fiber push-in technique and the chemical compositions of the fiber coatings were analyzed by scanning Auger microprobe analysis. 


\section{MATERIALS AND EXPERIMENTAL METHODS}

Polymer derived Hi-Nicalon fiber tows (1800 denier, 500 filaments/tow) with low oxygen content from Nippon Carbon Co. were used as the reinforcement. A dual layer of BN overcoated with $\mathrm{SiC}$ was applied on the fibers surfaces by $3 \mathrm{M}$ in two separate batches, batch 1 and 2, using a continuous chemical vapor deposition (CVD) reactor. The polyvinyl alcohol (PVA) sizing on the as-received fibers was burned off in air by passing through a tube furnace before coating the fibers. The BN coating was deposited at $\sim 1050{ }^{\circ} \mathrm{C}$ utilizing a proprietary precursor and was amorphous to partly turbostratic in nature. A thin overcoating of $\mathrm{SiC}$ was deposited to the $\mathrm{BN}$-coated fibers. The SiC layer was crystalline. The nominal coating thicknesses were $0.4 \mu \mathrm{m}$ for $\mathrm{BN}$, and $0.3 \mu \mathrm{m}$ for $\mathrm{SiC}$.

The elemental compositions of the fiber near the surface and of the fiber surface coatings were analyzed with a scanning Auger microprobe (Fisons Instruments Microlab Model 310-F). The fibers for this analysis were mounted on a stainless steel sample mount by tacking the ends with colloidal graphite. Depth profiling was performed by sequential ion-beam sputtering and Auger analysis. The ion etching was done with $3 \mathrm{keV}$ Argon ions rastered over an $\sim 1 \mathrm{~mm}^{2}$ area. The etch rate in $\mathrm{Ta}_{2} \mathrm{O}_{5}$ under these conditions was $0.05 \mathrm{~nm} / \mathrm{s}$. Auger electron spectroscopy (AES) analysis of the coated Hi-Nicalon fibers was performed using an electron beam current of $\sim 1.5 \mathrm{nA}$. The beam was rastered over a $2 \times 20 \mu \mathrm{m}$ area of the fiber with the long axis of the area aligned with the long axis of the fiber. Spectra were acquired in integral mode at a beam energy of $2 \mathrm{keV}$ and depth profiles were generated by plotting elemental peak areas against ion etch time. The atomic concentrations were calculated by dividing the peak areas by the spectrometer transmission function and the sensitivity factors for each peak, then scaling the results to total 100 percent. The sensitivity factors were derived from spectra of ion etched $\mathrm{Si}, \mathrm{B}, \mathrm{SiC}, \mathrm{BN}$, and $\mathrm{TiO}_{2}$ standards. The depth scale is from the $\mathrm{Ta}_{2} \mathrm{O}_{5}$ calibration and no attempt has been made to adjust for the actual etch rate for each material. Only the fibers with a smooth surface coating, rather than those having thick and rough coating morphologies, were used for Auger analysis.

The fiber-reinforced composites were fabricated by mpregnation of the fiber tows with the matrix slurry as described earlier (ref. 7). The precursor to the celsian matrix of $0.75 \mathrm{BaO}$ $0.25 \mathrm{SrO}-\mathrm{Al}_{2} \mathrm{O}_{3}-2 \mathrm{SiO}_{2}$ composition was synthesized by a solid state reaction method as reported elsewhere (ref. 8). The precursor powder consisted (ref. 8) of mainly $\mathrm{SiO}_{2}\left(\alpha\right.$-quartz) and $\mathrm{BaAl}_{2} \mathrm{O}_{4}$ phases with small amounts of $\mathrm{Ba}_{2} \mathrm{SiO}_{4}, \alpha-\mathrm{Al}_{2} \mathrm{O}_{3}$, and $\mathrm{Ba}_{2} \mathrm{Sr}_{2} \mathrm{Al}_{2} \mathrm{O}_{7}$ also present. This powder was made into a slurry by dispersing in an organic solvent and ball milling along with various organic additives which acted as binder, surfactant, deflocculant ind plasticizer. Tows of BN-SiC coated $\mathrm{Hi}-\mathrm{Nicalon}$ fibers were spread using rollers and coated with the matrix precursor by passing through the slurry. Excess slurry was squeezed out of the fiber tow before winding it (26 fiber tows/in.) on a rotating drum. The prepreg tape was allowed to dry and then cut to size. Unidirectional fiber-reinforced composites were prepared by prepreg tape lay up (12 plies) and warm pressing which resulted in a "green" composite. The fugitive organics were slowly burned out of the sample in air, followed by hot pressing under vacuum in a graphite die. The resulting composites were almost fully dense. The hot pressed fibe:-reinforced composite panel was surface polished and sliced into test bars $(\sim 50.4 \times 6.4 \times 1.9 \mathrm{~mm})$ for mechanical testing.

$\mathrm{X}$-ray diffraction (XRD) patterns were recorded at room temperature using a step scan procedure $\left(0.02^{\circ} / 2 \theta\right.$ step, time/step 0.5 or $\left.1 \mathrm{~s}\right)$ on a Phi ips ADP-3600 automated diffractometer equipped with a crystal mono-chromator employing copper $\mathrm{K}_{\alpha}$ radiation. Density was measured from dimensions and mass as well as by the Archimedes method. Microstructures of the polished cross-sections and fracture surfaces were observed in an optical microscope as well as by a JEOL JSM-840A scanning electron microscope (SEM). Prior to analysis, a thin carbon coating was evaporated onto the SEM specimens for electrical conduc ivity. 
Mechanical properties were determined from stress-strain curves recorded in three-point flexure using an Instron machine at a crosshead speed of $0.127 \mathrm{~cm} / \mathrm{min}(0.05 \mathrm{in} . / \mathrm{min})$ and support span (L) of $40 \mathrm{~mm}$. Strain gauges were glued to the tensile surfaces of the flexure test bars. The first matrix cracking stress, $\sigma_{m}$, was calculated from the stress-strain curves where the curve deviates from linearity. The elastic modulus of the composite was determined from the linear portion of the stress-strain curve.

Cyclic fiber push-in tests were performed using a desktop apparatus previously described (ref. 9), but with the addition of a symmetrically placed pair of capacitance gauges for displacement measurements. Thin sections of the composites, cut normal to the fiber axis with a diamond saw, and polished down to a $0.1 \mu \mathrm{m}$ finish on both top and bottom faces were tested. Final specimen thickness was typically about $3 \mathrm{~mm}$. Fibers were pushed in using a $70^{\circ}$-includedangle conical diamond indenter with a $10 \mu \mathrm{m}$ diameter flat base. To prevent the sides of the conical indenter from impacting the matrix, push-in distances were restricted to just a couple of microns. Unless otherwise noted, each test consisted of five cycles of loading and unloading between a selected maximum load and a minimum load of $0.01 \mathrm{~N}$ at room temperature in ambient atmosphere.

\section{RESULTS}

\subsection{Microstructure}

SEM micrographs taken from the polished cross-sections of the two composites (fig. 1) indicate uniform fiber distribution and good matrix infiltration within the fiber tows resulting in high composite density. Occasional pores within the fiber tows are present. The outer SiC coating has debonded from some of the fibers in both composites. However, the BN/SiC duplex coating was completely detached from some of the fibers in the CMC reinforced with batch 2 coated fibers as seen in figure 1(d) which represents the worst case (atypical). XRD patterns taken from the polished surface of the CMC panels indicated the presence of only monoclinic celsian. This implies that the desired monoclinic celsian phase is formed in situ, from the oxide precursor during hot pressing. No hexacelsian was detected from XRD.

\subsection{Mechanical Properties}

Typical stress-strain curves recorded in three-point flexure for the two composites are presented in figure 2. The stress-strain curve for a hot pressed celsian monolith is also shown for comparison. The monolith shows a modulus of $96 \mathrm{GPa}$, flexural strength of $131 \mathrm{MPa}$ and fails in a brittle mode as expected. Both CMCs show initial linear elastic behavior followed by deviation from linearity. This indicates load transfer to the fibers beyond the proportional limit indicating a true composite behavior. SEM micrographs of fracture surfaces after the flexure tests are shown in figure 3. Extensive long lengths of fiber pullout are observed for both composites indicating toughening behavior. Values of density, fiber volume fraction, elastic modulus and various mechanical properties are given in table I. Both the composites show high ultimate strength in accordance with the value of the fiber volume fraction. However, a large difference is observed in the values of $\sigma_{\mathrm{m}}$ for the two composites. This is quite surprising because both composites were processed under exactly similar conditions. The only difference was that the duplex BN/SiC coating on the fibers used for fabrication of the two composites were deposited in two different batches, but by the same vendor. The difference in fiber volume fractions in the two composites 
will have some effect on the residual thermal stresses, but not enough to account for the large difference seen in the $\sigma_{\mathrm{mc}}$ values.

\subsection{Fiber-Matrix Interface}

In order to determine whether differences in interfacial behavior were the source of the disparity in $\sigma_{\mathrm{mc}}$ for the two composites with "similar" BN/SiC interphase coatings, fiber push-in tests were carried out. A number of fibers were pushed in for each composite. Typical cyclic pushin curves at room temperature for the two composites with $\mathrm{BN} / \mathrm{SiC}$ interface coatings are shown in figure 4 . The data were analyzed by first subtracting the appropriate load-train compliance correction from the measured displacements. An estimate of frictional sliding stress, $\tau_{\text {friction }}$, was determined using the constant $\tau_{\text {friction }}$ model of Marshall and Oliver (ref. 10) which includes effects of residual stresses, but does not consider fiber roughness or Poisson expansion. Values of $\tau_{\text {friction }}$ were determined by fitting the compliance corrected data from the first reloading curve to the relationship:

$$
u=u_{0}+\left[F^{2} /\left(8 \pi^{2} r_{f}^{3} E_{f} \tau_{\text {friction }}\right)\right]
$$

where $u$ is the fiber end displacement, $u_{0}$ is the residual fiber end displacement after the previous unloading, $F$ is the applied load, $r_{f}$ is the fiber radius, and $E_{f}$ is the fiber modulus. While neglecting Poisson expansion of the fibers leads to an overestimation of $\tau_{\text {friction }}$ values, the relative comparison of $\tau_{\text {friction }}$ for different coatings should be valid. In addition. a debond initiation stress, $\sigma_{d}$, could be calculated from the debond initiation load, $F_{d}$, (load at which fiber end begins to move during first loading cycle) by the relation

$$
\sigma_{\mathrm{d}}=\mathrm{F}_{\mathrm{d}} / \pi \mathrm{r}_{\mathrm{f}}^{2}
$$

The results of fiber push-in data are summarized in table II. For the two composites with $\mathrm{BN} / \mathrm{SiC}$ interface coatings, values of $\sigma_{\mathrm{d}}$ are $1.95 \pm 0.87$ and $0.31 \pm 0.14 \mathrm{GPa}$ and $\tau_{\text {friction }}$ are $121.2 \pm 48.7$ and

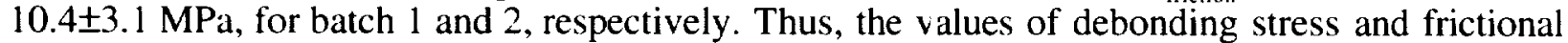
sliding stress are much higher for composites with batch 1 coated fiber than with batch 2 . Such a large difference in the values of $\sigma_{d}$ and $\tau_{\text {friction }}$ for the two composites, fabricated under same conditions and having "similar" interface coatings, is quite surprising. To help explain this difference, elemental compositions of the duplex $\mathrm{BN} / \mathrm{SiC}$ coatings on the fibers were analyzed by scanning Auger microprobe.

\subsection{Scanning Auger Analysis}

Elemental composition depth profiles obtained from szanning Auger microprobe analysis for the two batches of $\mathrm{BN} / \mathrm{SiC}$ coatings on Hi-Nicalon fibers are shown in figure 5 . The batch 1 coating consists of $\sim 0.7 \mu \mathrm{m}$ thick outer layer of slightly silicon-rich $\mathrm{SiC}$ followed by a boron-rich BN layer $\sim 1.5 \mu \mathrm{m}$ thick. The BN layer also contains $\sim 15$ at $\%$ of carbon and $\sim 2$ percent oxygen. The thickness of the dual coating on this filament is r auch higher than the nominal coating thickness of $0.4 \mu \mathrm{m} \mathrm{BN}$ and $0.3 \mu \mathrm{m} \mathrm{SiC}$. The batch 2 coating consists of $\sim 0.15 \mu \mathrm{m}$ thick Si-rich $\mathrm{SiC}$ followed by $\sim 0.6 \mu \mathrm{m}$ of carbon rich "BN." A carbon layer is also present between the $\mathrm{SiC}$ and " $\mathrm{BN}$ " coatings. Another predominantly carbon layer is observed between the " $\mathrm{BN}$ " and the 
fiber surface. Thus the coatings deposited on the fibers in the two batches differ in composition and structure.

\section{DISCUSSION}

Microscopic examination (figs. 6 and 7) of the fiber pushed-in samples indicated the presence of wear debris at the interface. The wear debris consists of thick sections of coating in composite \#1 (fig. 6) but only of thin sublayers of coating in composite \#2 (fig. 7). The debonding occurs primarily between the innermost coating and the fiber for both composites. Therefore, according to the Auger results, interfacial sliding occurs at the fiber(SiC)/BN interface for composite \#1 and at the fiber( $\mathrm{SiC}$ )/carbon interface for composite $\# 2$. Comparison of $\sigma_{\mathrm{d}}$ and $\tau_{\text {friction }}$ values for the two composites indicate that the interface is more strongly bonded and the frictional sliding forces are higher between fiber/BN in composite \#1 than the fiber/carbon interface in composite \#2. Brennan et al. (ref. 11) obtained a value of $9.9 \pm 3.5 \mathrm{MPa}$ for $\tau_{\text {friction }}$ for the Nicalon/LAS composites, from a similar fiber push-in method using the analysis of Marshall and Oliver (ref. 10). This is consistent with the observation of in situ formation of a thin carbon layer at the fiber/matrix interface during processing of this composite. $\tau_{\text {friction }}$ values of $139 \pm 95$ and $124 \pm 71 \mathrm{MPa}$ have been reported (refs. 11 and 12) for Nicalon/BN/SiC/BMAS and Nicalon/BN/SiC/LAS glass-ceramic matrix composites from the fiber push-in technique as used in the current study. The $\mathrm{BN} / \mathrm{SiC}$ fiber coatings in these composites were also applied by $3 \mathrm{M}$ and the scanning Auger microprobe analysis indicated these coatings to be similar to batch 1 coatings of the present work. Several factors such as residual thermal clamping stresses, fiber roughness, and modulus and thickness of the fiber coating which can control the former factors contribute to the value of $\tau_{\text {friction. }}$ However, values of $\tau_{\text {friction }}$ differing by a factor of about 12 in the two composites of the present study may be attributed primarily to the much lower sliding friction between $\mathrm{C} / \mathrm{SiC}$ versus $\mathrm{BN} / \mathrm{SiC}$ interfaces and also to the difference in the size of the wear debris at the interface.

By using a simple energy balance approach, in determining the stress necessary to propagate cracks in brittle solids, the following equation has been derived (refs. 13 and 14) for the matrix cracking stress, $\sigma_{m c}$, in a composite consisting of a low failure strain matrix reinforced with high failure strain continuous fibers:

$$
\sigma_{m c}=\left[\left(12 \tau_{\text {friction }} \Gamma_{m} V_{f}^{2} E_{f} E_{c}^{2}\right) /\left\{r_{f}\left(1-V_{f}\right) E_{m}^{2}\right\}\right]^{1 / 3}
$$

where $\Gamma_{m}$ is the matrix fracture surface energy, $V_{f}$ is the fiber volume fraction, $E_{c}, E_{m}$, and $E_{f}$ are the elastic moduli of the composite, matrix and fiber, respectively and other terms have the same meaning as above. It is apparent from this equation that the first matrix cracking stress can be enhanced by increasing fiber-matrix interfacial sliding stress, by using fibers of smaller radius, and by increasing the volume fraction of fibers. It might also be increased by using low modulus matrix and high modulus fibers. The matrix microcracking may also be suppressed by placing the matrix in compression through choosing $\alpha_{i}>\alpha_{n}$, although for isotropic fibers this will result in contraction of the fibers away from the matrix and a potential decrease in fiber-matrix shear strength. It is important to optimize the fiber-matrix bond strength as too strong a bond will result in a brittle composite with low toughness. By using values of various parameters, as given above, the ratio of $\left(\sigma_{\mathrm{mc}}\right)_{\text {batch } 1}$ and $\left(\sigma_{\mathrm{mc}}\right)_{\text {batch } 2}$ for the two composites was calculated from equation (3) to be 3.29. This is in very good agreement with a value of 3.57 for the ratio of measured $\sigma_{\mathrm{mc}}$ values. 


\section{SUMMARY OF RESULTS}

A large difference in first matrix cracking stresses and fiber/matrix interface characteristics were observed for celsian matrix composites reinforced with Hi-Nicalon fibers which had been pre-coated with a dual layer of $\mathrm{BN} / \mathrm{SiC}$ coating in two different batches by the same vendor. From scanning Auger analysis, this difference in mechanical behavior of the two composites was traced back to the differences in the compositions of the interface coatings. Carbon layers were present between the fiber and the $\mathrm{BN}$, and also between the $\mathrm{BN}$ and $\mathrm{SiC}$ coatings in the composite showing lower values of first matrix cracking stress and frictional sliding stress. During fiber push-in and mechanical testing, debonding and fiber sliding occurred at the interface between the fiber and the innermost coating.

\section{CONCLUSIONS}

The composition of the fiber surface coating plays an important role in controlling the interface at which the debonding occurs. This determines the fiber/matrix interfacial shear and frictional sliding behavior which in turn controls the first matrix cracking stress of the composites, in qualitative agreement with the micromechanical models. This study also indicates that obtaining reproducible and consistent fiber coatings from commercial sources is a problem.

\section{REFERENCES}

1. N.P. Bansal: "Ceramic Fiber-Reinforced Glass-Ceramic Matrix Composite," U.S. Patent $5,214,004$, May 25, 1993.

2. N.P. Bansal, "Method of Producing a Ceramic Fiber-Reinforced Glass-Ceramic Matrix Composite," U.S. Patent 5,281,559, January 25, 1994.

3. N.P. Bansal, "CVD SiC Fiber-Reinforced Barium Aluminosilicate Glass-Ceramic Matrix Composites," Mater. Sci. Eng., A220 [1-2], pp. 129--139 (1996).

4. N.P. Bansal, P. McCluskey, G. Linsey, D. Murphy, and G. Levan, "Nicalon Fiber-Reinforced Celsian Glass-Ceramic Matrix Composites," Proceedings of Annual HITEMP Review, Cleveland, $\mathrm{OH}$, October $23-25,1995$. NASA CP-10178, Vol. III, pp. 41-1 to 41-14 (1995).

5. N.P. Bansal, "Strong and Tough Hi-Nicalon Fiber-Reinforced Celsian Matrix Composites," $J$. Am. Ceram. Soc., 80 [9], pp. 2407-2409 (1997).

6. N.P. Bansal and J.I. Eldridge, Hi-Nicalon Fiber-Rıinforced Celsian Matrix Composites: Influence of Interface Modification, J. Mater. Res., 13 [6], pp. 1530-1537 (1998).

7. N.P. Bansal and J.A. Setlock, "Processing of Small Diameter Fiber-Reinforced Celsian Composites," NASA TM-107356 (1996).

8. N.P. Bansal, "Solid State Synthesis and Properties of Monoclinic Celsian," J. Mater. Sci., in press (1999).

9. J.I. Eldridge, “Desktop Fiber Push-Out Apparatus,” NASA TM-105341 (1991).

10. D.B. Marshall and W.C. Oliver, "Measurement of Int erfacial Mechanical Properties in FiberReinforced Ceramic Composites," J. Am. Ceram. So :., 70 [8], pp. 542-548 (1987).

11. J.J. Brennan, W. Allen, S.R. Nutt, and Y. Sun, "Interfa:ial Studies of Coated Fiber Reinforced Glass-Ceramic Matrix Composites," UTRC Report R92-970150-1, November 30, 1992.

12. E.Y. Sun, S.R. Nutt, and J.J. Brennan, "Interfacial Microstructure and Chemistry of SiC/BN Dual-Coated Nicalon Fiber-Reinforced Glass-Ceramic Matrix Composites," J. Am. Ceram. Soc., 77 [5], pp. 1329-1339 (1994). 
13. J. Aveston, G.A. Cooper, and A. Kelly, "Single and Multiple Fracture," in The Properties of Fiber Composites, IPC Sci. and Technol. Press, Guildford, 1971, pp. 15-26.

14. B. Budiansky, J.W. Hutchinson and A.G. Evans, "Matrix Fracture in Fiber-Reinforced Ceramics," J. Mech. Phys. Solids, 34 [2], pp. I67-189 (1986).

TABLE I.-MECHANICAL PROPERTIES ${ }^{a}$ OF Hi-NICALON/BSAS COMPOSITES [Unidirectional; 12 Plies.]

\begin{tabular}{|c|c|c|c|c|c|c|c|c|}
\hline $\begin{array}{c}\text { Interface } \\
\text { coating }\end{array}$ & CMC panel number & $\begin{array}{c}\text { Density } \\
\left(\mathrm{g} / \mathrm{cm}^{3}\right)\end{array}$ & $\mathrm{V}_{\mathrm{f}}$ & $\begin{array}{c}\mathrm{E}, \\
\mathrm{GPa}\end{array}$ & $\begin{array}{c}\sigma_{\mathrm{mc}}, \\
\mathrm{MPa}\end{array}$ & $\begin{array}{c}\varepsilon_{\mathrm{mc}}, \\
\text { percent }\end{array}$ & $\begin{array}{c}\sigma_{\mathrm{u}}, \\
\mathrm{MPa}\end{array}$ & $\begin{array}{c}\varepsilon_{\mathrm{u}}, \\
\text { percent }\end{array}$ \\
\hline $\begin{array}{c}\mathrm{BN} / \mathrm{SiC} \\
(\mathrm{Batch} \text { 1) }\end{array}$ & HI-NIC-BSAS-1-29-96 & 3.05 & 0.43 & $164 \pm 4$ & $436 \pm 32$ & $0.27 \pm 0.01$ & $904 \pm 54$ & $0.73 \pm 0.07$ \\
\hline $\begin{array}{c}\text { BN/SiC } \\
\text { (Batch 2) }\end{array}$ & HI-NIC-BSAS-6-24-97 & 3.09 & 0.32 & 137 & 122 & 0.091 & 759 & 1.041 \\
\hline
\end{tabular}

Measured at room temperature in 3-point flexure.

TABLE II.-FIBER PUSH-IN DATA FOR Hi-NICALON/BSAS COMPOSITES

[Unidirectional; 12 Plies.]

\begin{tabular}{|l|c|c|c|c|c|}
\hline $\begin{array}{c}\text { Interface } \\
\text { coating }\end{array}$ & CMC panel number & $\begin{array}{c}\text { Number } \\
\text { of tests }\end{array}$ & $\mathrm{V}_{\mathrm{f}}$ & $\begin{array}{c}\sigma_{\mathrm{d}}, \\
\mathrm{GPa}\end{array}$ & $\begin{array}{c}\tau_{\text {friction }}, \\
\mathrm{MPa}\end{array}$ \\
\hline $\begin{array}{l}\mathrm{BN} / \mathrm{SiC} \\
\text { (Batch 1) }\end{array}$ & HI-NIC-BSAS-6-6-96 & 50 & 0.39 & $1.95 \pm 0.87$ & $121.2 \pm 48.7$ \\
\hline $\begin{array}{l}\mathrm{BN} / \mathrm{SiC} \\
\text { (Batch 2) }\end{array}$ & HI-NIC-BSAS-6-24-97 & 19 & 0.32 & $0.31 \pm 0.14$ & $10.4 \pm 3.1$ \\
\hline
\end{tabular}



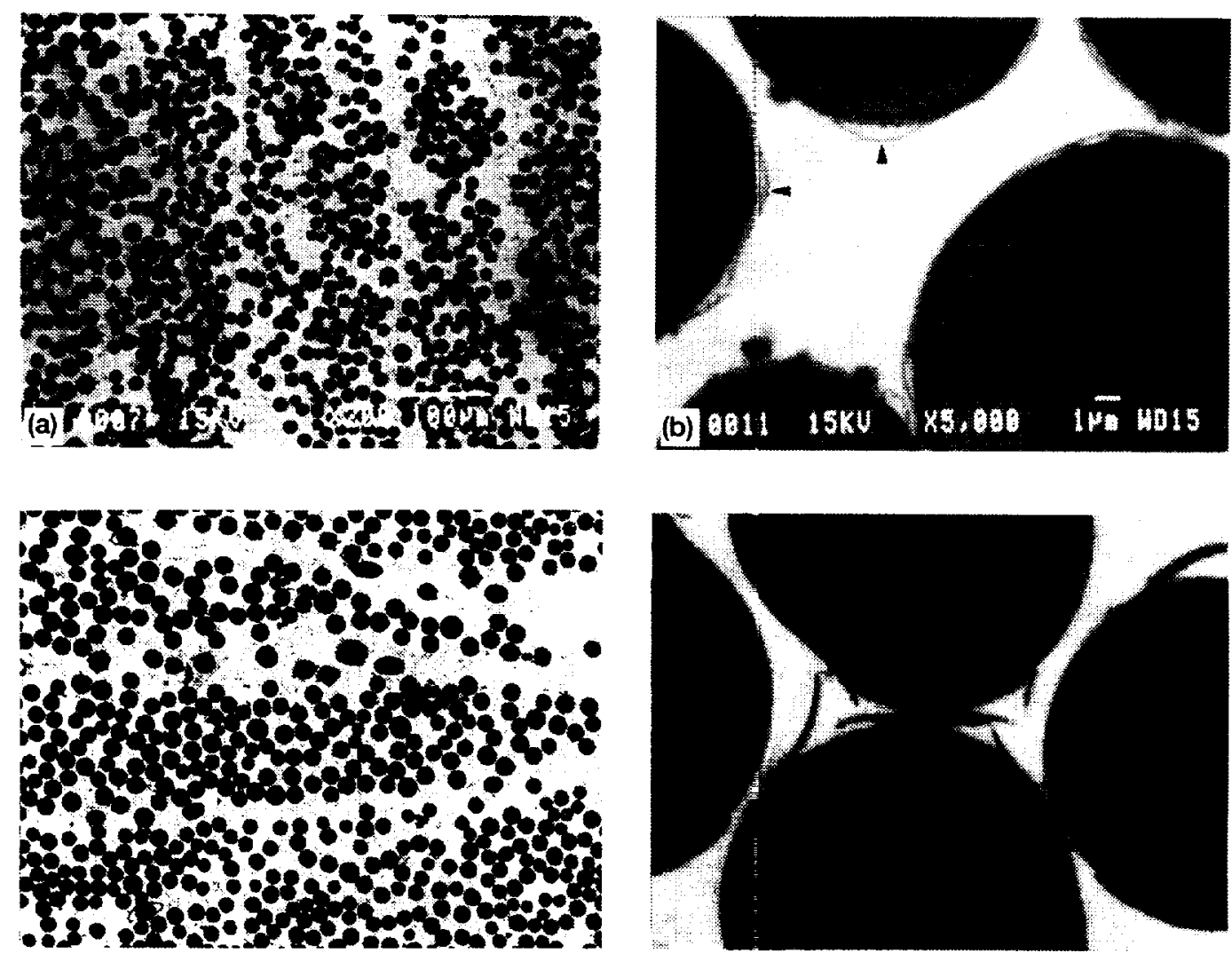

(c)

$$
100 \mu \mathrm{m}
$$

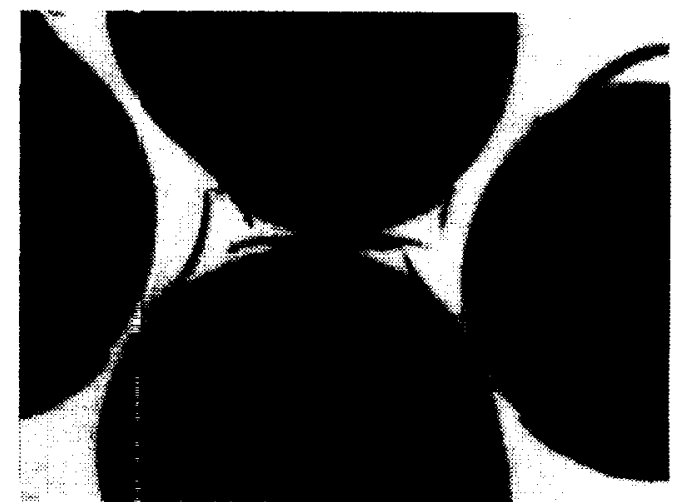

(d)

$1 \mu \mathrm{m}$

Figure 1.-SEM micrographs of polished cross-sections of unidirectional HiNicalon/BN/ SiC/ Celsian composites: $(a, b)$ batch 1 composite and(c, d) l)atch 2 composite. 


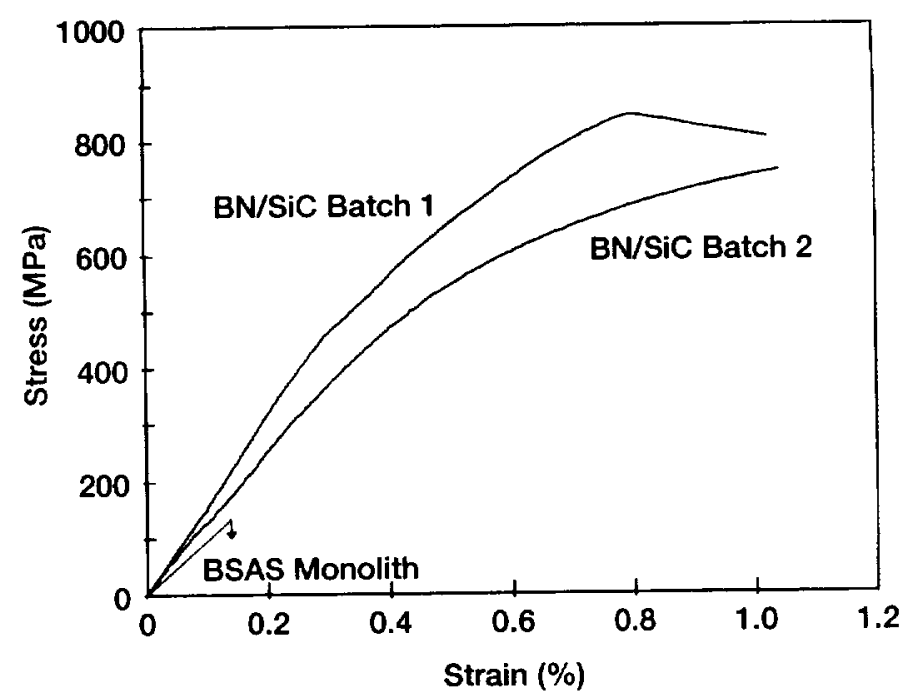

Figure 2.-Apparent stress-strain curves recorded in three-point flexure for celsian matrix composites reinforced with Hi-Nicalon fibers coated with $\mathrm{BN} / \mathrm{SiC}$ in two separate batches. Also shown for comparison are the results for a hot pressed BSAS monolith. 

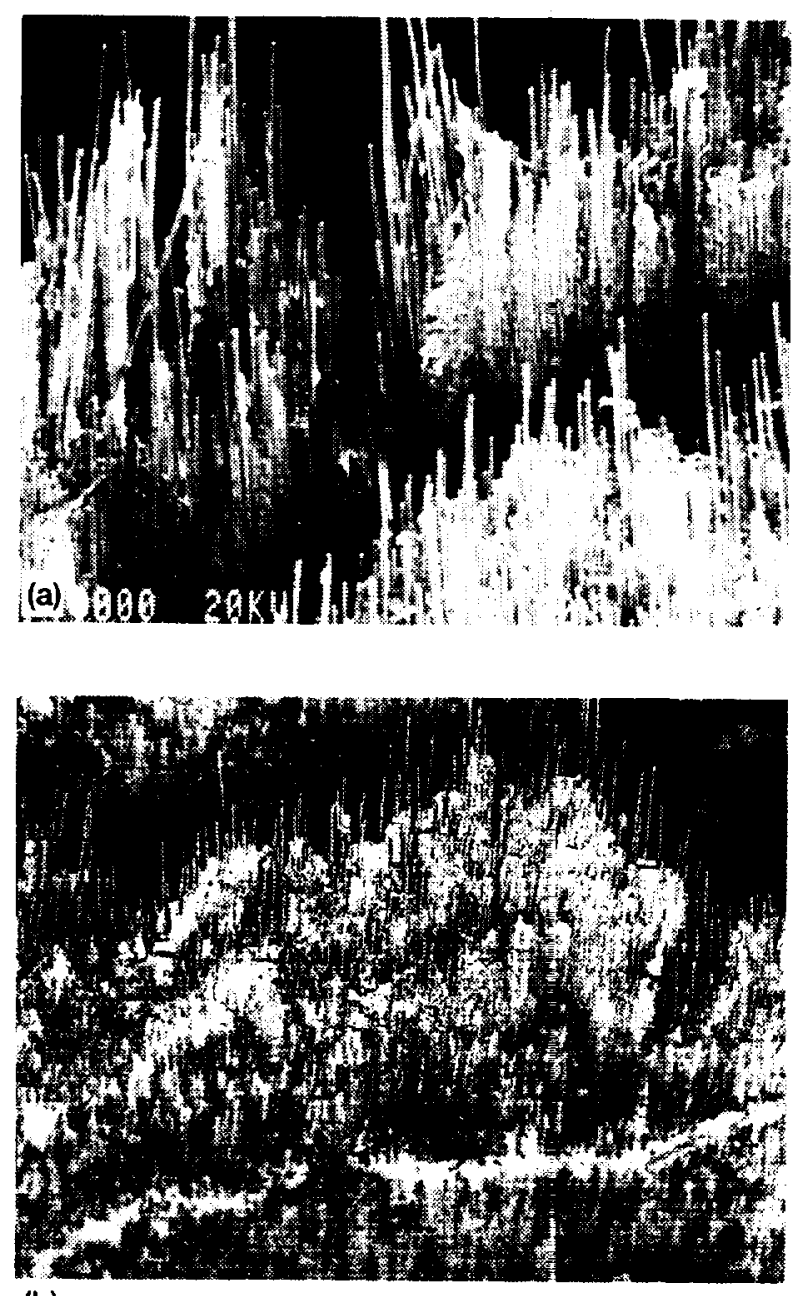

(b)

$100 \mu \mathrm{m}$

Figure 3.-SEM micrographs showing fracture surfaces of celsian matrix composites reinforced with Hi-Nicalon fibers coated with BN/SiC; in two separate batches: (a) batch 1 coating, (b) batc $h 2$ coating. 


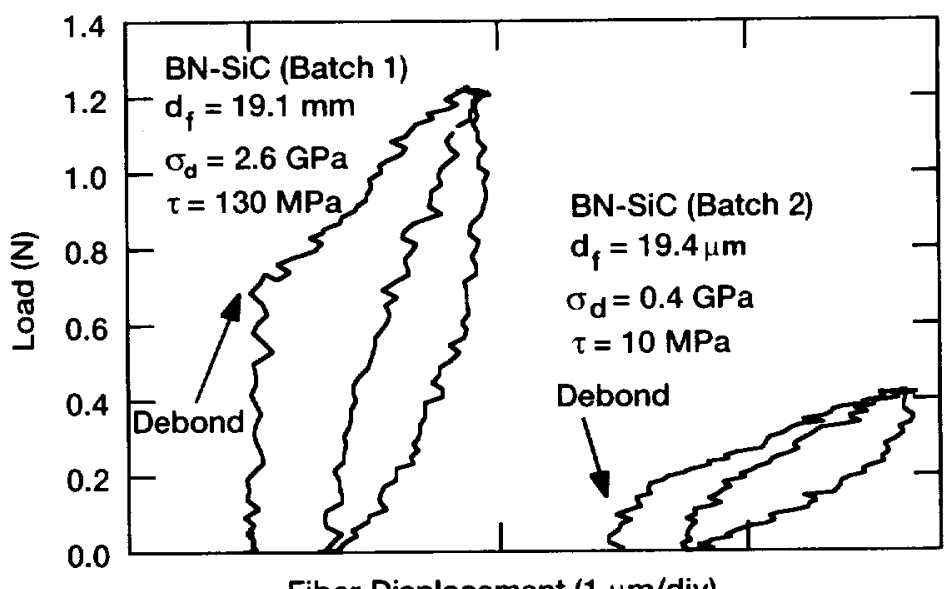

Fiber Displacement $(1 \mu \mathrm{m} / \mathrm{div})$

Figure 4.-Load versus fiber displacement curves recorded during fiber push-in testing of celsian matrix composites reinforced with $\mathrm{Hi}$-Nicalon fibers coated with $\mathrm{BN} / \mathrm{SiC}$ in two separate batches. 

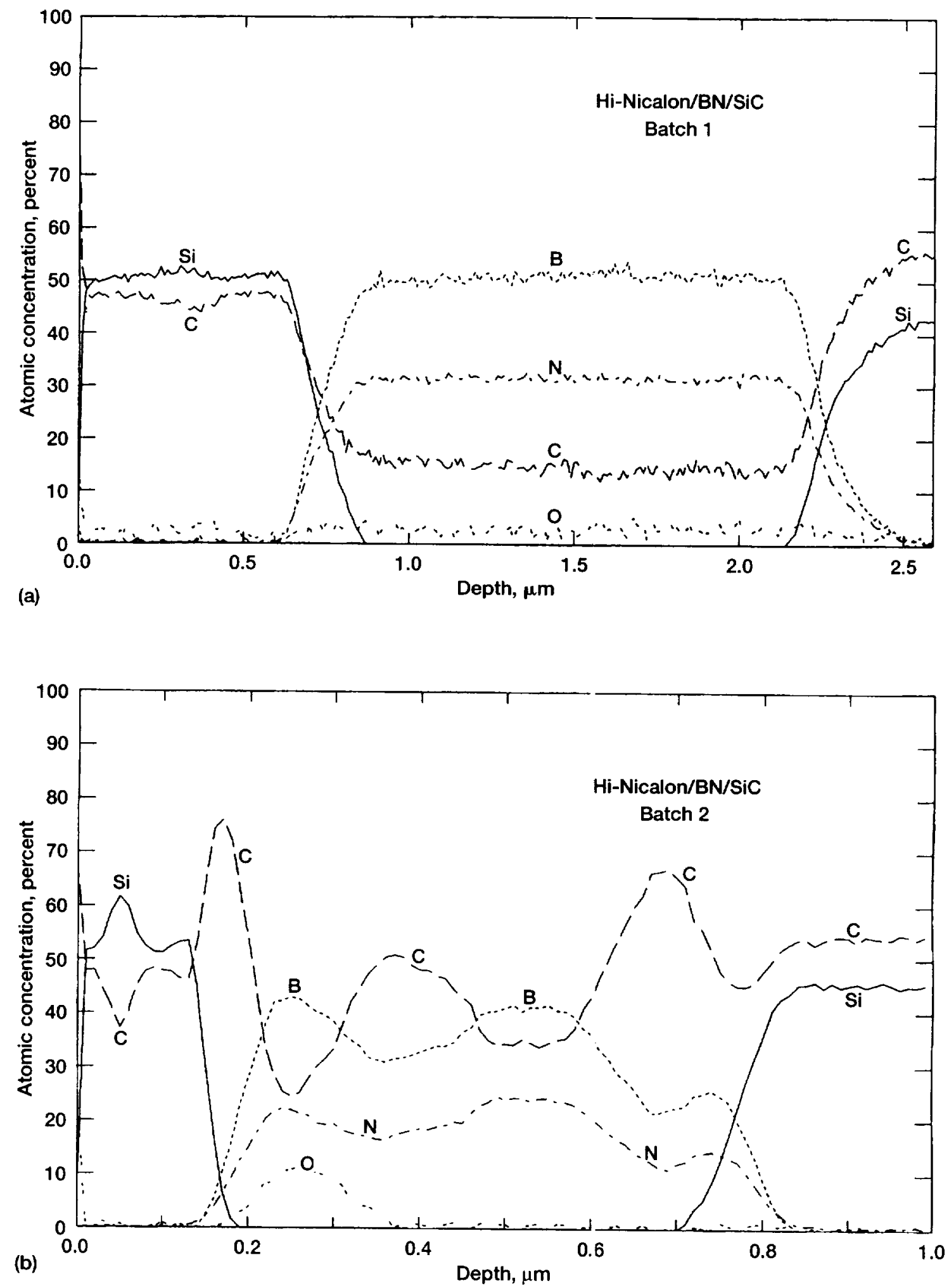

Figure 5.-Scanning Auger microprobe depth profiles of varicus elements for Hi-Nicalon fibers having a duplex BN/SiC surface coating deposited by CVD: (a) coatir $g$ batch \#1, and (b) coating batch \#2. 

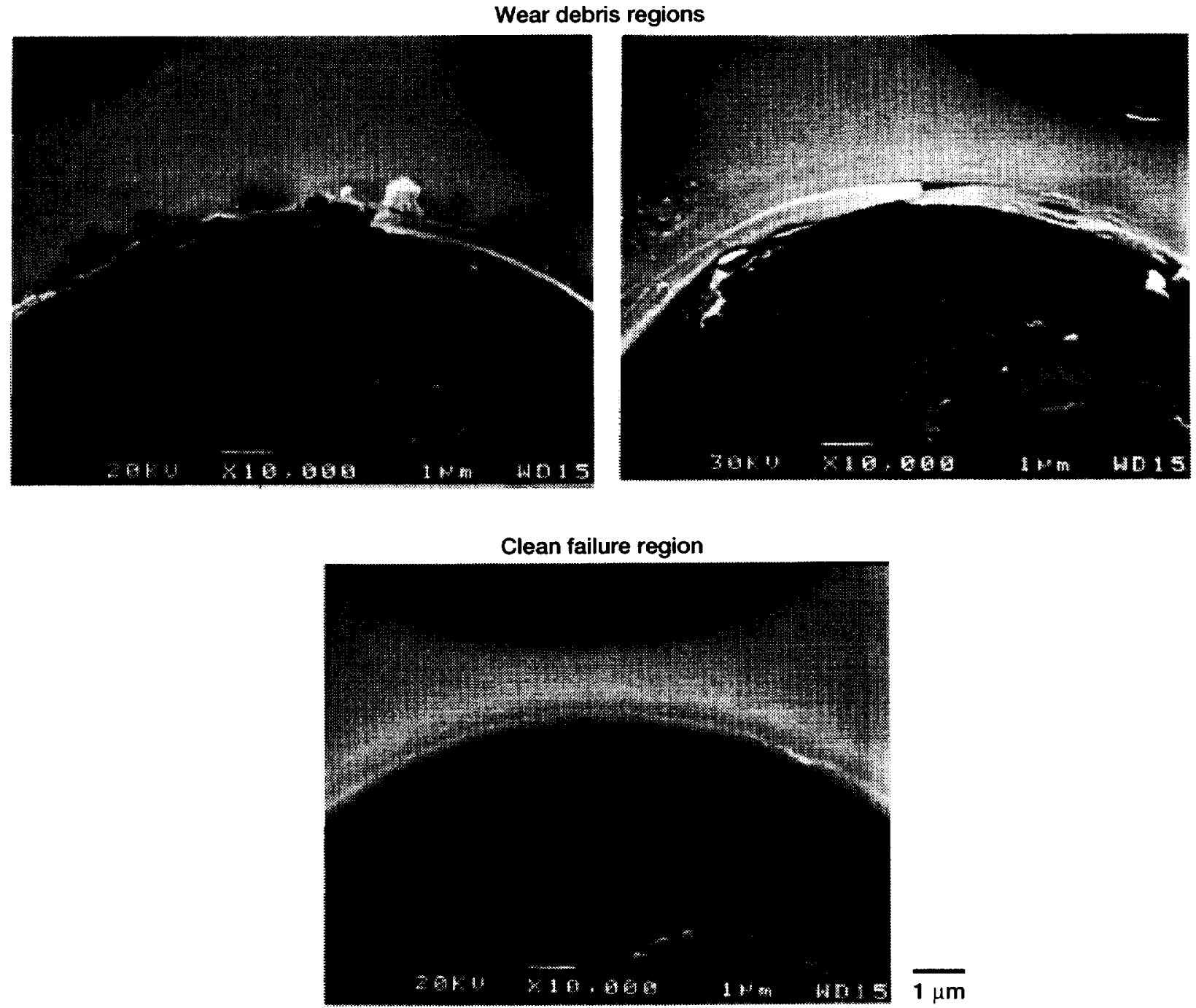

Figure 6.-SEM micrographs showing interface failure during fiber push-in for celsian matrix composites reinforced with $\mathrm{Hi}-\mathrm{Nicalon}$ fibers coated with $\mathrm{BN} / \mathrm{SiC}$ in batch 1. 
Wear debris regions
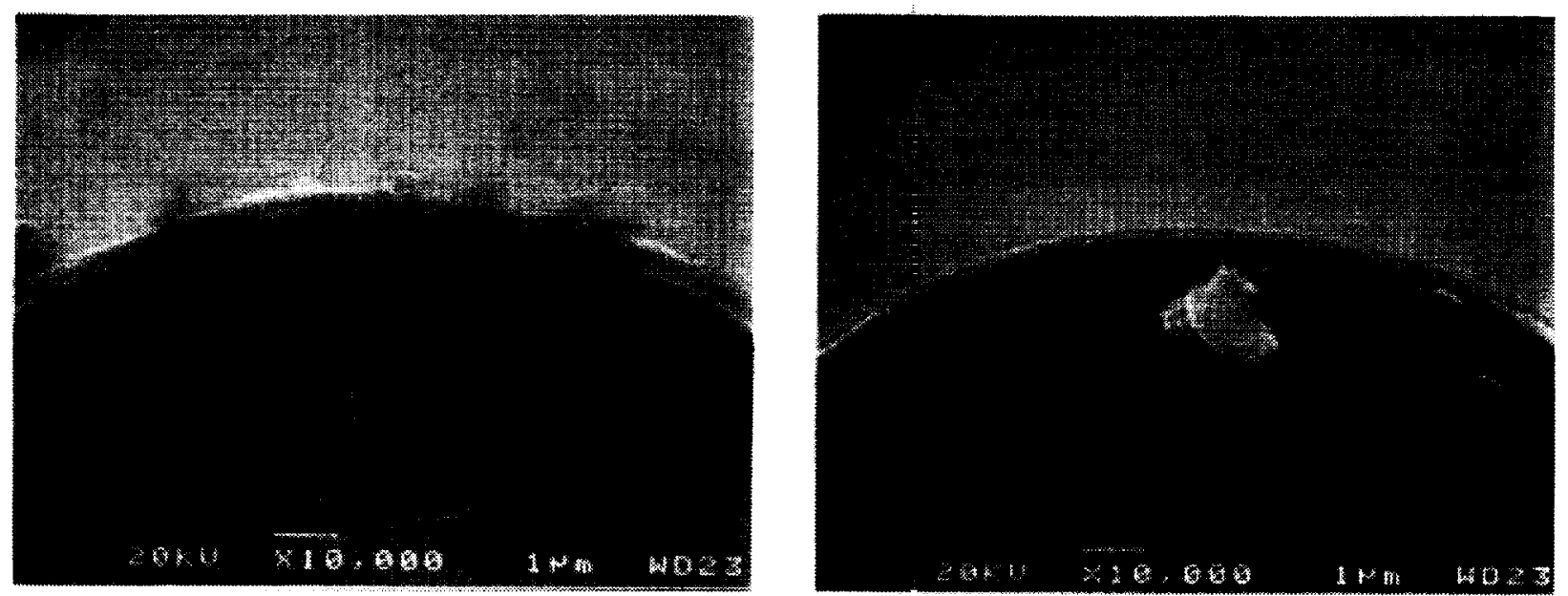

Clean failure region

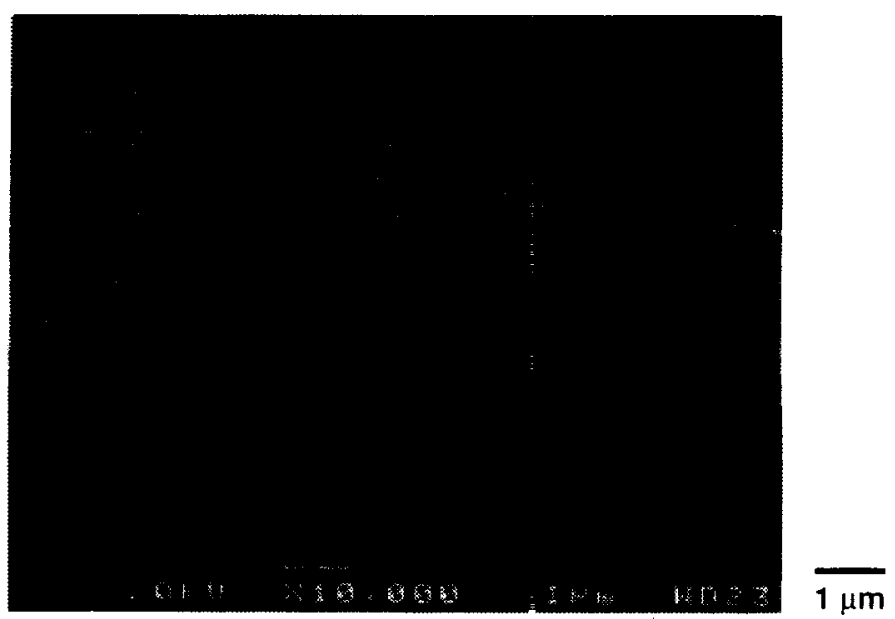

Figure 7.-SEM micrographs showing interface failure during tiber push-in for celsian matrix composites reinforced with Hi-Nicalon fibers coated with $\mathrm{BN} / \mathrm{SiC}$ in batc 12. 


\begin{tabular}{|c|c|c|c|}
\hline \multicolumn{3}{|c|}{ REPORT DOCUMENTATION PAGE } & $\begin{array}{l}\text { Form Approved } \\
\text { OMB No. 0704-0188 }\end{array}$ \\
\hline \multicolumn{4}{|c|}{$\begin{array}{l}\text { Public reparting burden for this collection of information is estimated to average } 1 \text { hour per response, including the time for reviewing instructions. searching existing dala sources, } \\
\text { gathering and maintaining the data needed, and completing and reviewing the collection of intormation. Send comments regarding this burden estimate or any other aspect of this } \\
\text { collection of information including suggestions for reducing this burden, } 10 \text { Washington Headquarters Services. Directorate for Intormation Operations and Reports, } 1215 \text { Jefferson } \\
\text { Davis Highway. Sulte 1204. Arlington. VA 22202-4302. and to the Office of Management and Budget. Paperwork Reduction Project (0704-0188). Washington, DC 20503. }\end{array}$} \\
\hline 1. AGENCY USE ONLY (Leave blank) & $\begin{array}{l}\text { 2. REPORT DATE } \\
\text { December } 1998\end{array}$ & \multicolumn{2}{|c|}{$\begin{array}{l}\text { 3. REPORT TYPE AND DATES COVERED } \\
\text { Technical Memorandum }\end{array}$} \\
\hline \multirow{2}{*}{\multicolumn{3}{|c|}{$\begin{array}{l}\text { 4. TITLE AND SUBTITLE } \\
\text { Effects of Fiber Coating Composition on Mechanical Behavior of Silicon Carbide } \\
\text { Fiber-Reinforced Celsian Composites }\end{array}$}} & \multirow{3}{*}{$\begin{array}{l}\text { 5. FUNDING NUMBERS } \\
\text { WU-52.3-21-13-00 }\end{array}$} \\
\hline & & & \\
\hline \multicolumn{3}{|c|}{$\begin{array}{l}\text { 6. AUTHOR(S) } \\
\text { Narottam P. Bansal and Jeffrey I. Elderidge }\end{array}$} & \\
\hline $\begin{array}{l}\text { 7. PERFORMING ORGANIZATION NA } \\
\text { National Aeronautics and } \mathrm{S}_{\mathrm{P}} \\
\text { Lewis Research Center } \\
\text { Cleveland, Ohio } 44135-31\end{array}$ & $\begin{array}{l}\text { S) AND ADDRESS(ES) } \\
\text { Administration }\end{array}$ & & $\begin{array}{l}\text { 8. PERFORMING ORGANIZATION } \\
\text { REPORT NUMBER } \\
\text { E- } 11443\end{array}$ \\
\hline $\begin{array}{l}\text { 9. SPONSORING/MONITORING AGEI } \\
\text { National Aeronautics and S } \\
\text { Washington, DC } 20546-00\end{array}$ & $\begin{array}{l}\text { NAME(S) AND ADDRESS(ES } \\
\text { Administration }\end{array}$ & & $\begin{array}{l}\text { 10. SPONSORING/MONITORING } \\
\text { AGENCY REPORT NUMBER } \\
\text { NASA TM-1998-208832 }\end{array}$ \\
\hline
\end{tabular}

\section{SUPPLEMENTARY NOTES}

Narottam P. Bansal and Jeffrey I. Elderidge, NASA Lewis Research Center. Responsible person,

12a. DISTRIBUTION/AVAILABILITY STATEMENT

12b. DISTRIBUTION CODE

Unclassified - Unlimited

Subject Category: 24

Distribution: Nonstandard

This publication is available from the NASA Center for AeroSpace Information. (301) 621-0390.

13. ABSTRACT (Maximum 200 words)

Celsian matrix composites reinforced with Hi-Nicalon fibers, precoated with a dual layer of BN/SiC by chemical vapor deposition in two separate batches, were fabricated. Mechanical properties of the composites were measured in threepoint flexure. Despite supposedly identical processing, the composite panels fabricated with fibers coated in two batches exhibited substantially different mechanical behavior. The first matrix crack-ing stresses ( $\sigma_{\text {mc }}$ ) of the composites reinforced with fibers coated in batch 1 and batch 2 were 436 and $122 \mathrm{MPa}$. respectively. This large difference in $\sigma_{\mathrm{mc}}$ was attributed to differences in fiber sliding stresses $\left(\tau_{\text {trittinn }}\right), 121.2 \pm 48.7$ and $10.4 \pm 3.1 \mathrm{MPa}$. respectively, for the two composites as determined by the fiber push-in method. Such a large difference in values of $\tau_{\text {irictiun }}$ for the two composites was found to be due to the difference in the compositions of the interface coatings. Scanning Auger microprobe analysis revealed the presence of carbon layers between the fiber and BN, and also between the BN and $\mathrm{SiC}$ coatings in the composite showing lower $\tau_{\text {finctiun }}$. This resulted in lower $\sigma_{\text {mic. }}$ in agreement with the ACK theory. The ultimate strengths of the two com-posites, 904 and $759 \mathrm{MPa}$, depended mainly on the fiber volume fraction and were not significantly effected by $\tau_{\text {triction }}$ values, as expected. The poor reproducibility of the fiber coating composition between the two batches was judged to be the primary source of the large differences in performance of the two composites.

14. SUBJECT TERMS

Ceramic composite; Interface: Mechanical properties; Microstructure Auger analysis 20

16. PAICE CODE

\begin{tabular}{|c|c|c|}
\hline $\begin{array}{c}\text { 17. SECURITY CLASSIFICATION } \\
\text { OF REPORT } \\
\text { Unclassified }\end{array}$ & $\begin{array}{c}\text { 18. SECURITY CLASSIFICATION } \\
\text { OF THIS PAGE } \\
\text { Unclassified }\end{array}$ & $\begin{array}{c}\text { 19. SECURITY CLASSIFICATION } \\
\text { OF ABSTRACT } \\
\text { Unclassificd }\end{array}$ \\
\hline
\end{tabular}

NSN 7540-01-280-5500 
